\title{
屈折効果を利用した縦型人エリーフシステムの 特性について
}

\author{
合田良実1 \\ 1フェロー会員 工博 横浜国立大学名誉教授 （株）エコー 顧問 \\ （テ110-0014 東京都台東区北上野 2-6-4）
}

\begin{abstract}
縦型人エリーフシステムは, 細長い潜堤を汀線と直角に複数基を配置した新形式の人エリーフである. 先端部および繸斜面による波の屈折作用によって天端上の波高を増大させ，波を効果的に砕かせて堿衰さ せる機能を持つ.この新システムについては, これまでに小規模の室内模型実験および数值計算によって その特性を検討してきた。 リーフシステム周辺の波高分布などが算定可能となり，これまでの横型人エリ 一フに対する優位性が例証された。しかし，これを実用化するにはさらに大規模の模型実験等が必要であ るため, これまでの研究成果を取りまとめ, 今後の開発の参考に供するものである.
\end{abstract}

Key Words : Articial reefs, londitudinal reef system, wave attenuation, wave-induced currents, parabolic equation, refraction effects.

\section{1. まえがき}

わが国の海岸の多くは, 恒常的な漂砂の供給不足 に起因する海岸侵食に苦しめられている.このため, 各地でいろいろな海岸保全対策を講じてきており, なかでも近年は離岸堤の施工事例が増えている. 特 に, 1999年の海岸法の改正において離岸堤と砂浜が 海岸保全施設として位置付けられたことにより, 離 岸堤がさらに数多く建設されるものと予想される.

もっとも, 標準型の離岸堤は天端が海面上に現れ ているため, なぎさを散策する人々からは海の眺め を阻害するとして嫌われる.このため, 最近は天端 を海面下 $1 \sim 2 \mathrm{~m}$ に抑え，幅を数十而に広げた人エリ ーフ（幅広潜堤）が好まれるようになっている. 本 論文では, 以下に紹介する新形式の人エリーフと区 別するために，これを横型人エリーフと呼ぶ.

横型人エリーフについては宇多ほが ${ }^{1)}$ が提唱して 以来, 数多くの実験や現地観測が行われてきた. 波 浪減衰は天端上での砕波, リーフ透水層内の流体抵 抗, 天端表面の摩摖抵抗などによるもので, なかで も砕波减衰が主役である. 大中・吉沢2)が神奈川県 湯河原海岸の人エリーフで観測した事例では, 当初 の幅 $32 \mathrm{~m}$ から幅 $70 \mathrm{~m}$ に拡幅されたことによる波高 伝達率の低下が $1 \sim 2$ 割程度と報告されている.

自然の岩礁地帯を観察すると, 波は屈折しながら

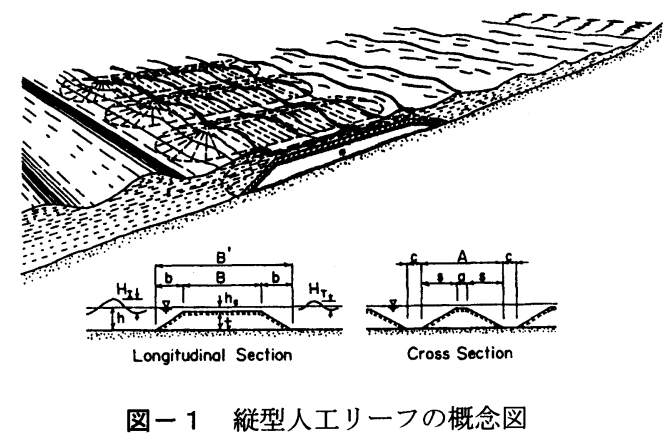

岩礁上に寄り集まり，そこで効率よく砕波させられ ている.人エリーフにおいてもこううした波の屈折効 果を利用することによって，砕波減衰機能をいっそ う高めることが期待される．著者はこうした観点か ら縦型傾斜式離岸堤と称する形式の人エリーフを提 唱し, いろいろ研究を行ってきた ${ }^{3) ~ 8)}$. このリーフ は図一 1 に示すように, 潜堤を汀線と直角に複数基 配置したシステムである.波は先端の半円球状の地 形による屈折だけでなく, 縦斜面によっても屈折し 天端上へ波高が集中する．このため，横型人エリー フよりも低い入射波高で砕波減衰が生じる.

本論文では，簡単のためにこれを縦型人エリーフ システムと呼ぶ. 図中の記号に示すように, $a$ は波 
の進行方向から見た天端長, $B$ は波の進行方向の天 端幅, $b$ は前後斜面の投影長, $s$ は縦斜面の投影幅, $c$ は海底面での潜堤間の間隙長, $h_{c}$ は天端水深, $h$ は水深, $t$ は潜堤の高さである.

この縌型リーフは, 通常の横型リーフに比べて反 射率およびシステム背後の水位上昇が小さい特長が ある. 予備的実験 ${ }^{3)}$ では反射率が $5 \%$ 前後, 水位上 昇が波高の 0 4\%の結果が得られている. また小型 の舟が潜堤間を通航できるので, 斜面や天端を利用 した海藻・草の育成など水産協調型施設としても利 用可能である. さらに, 作業船も潜堤間の水域に倸 留できるので, 天端被覆材の据付・補修なども容易 であり，天端の一部を干潮面以上に高めることも可 能である。

しかしながら，この縌型人エリーフを害際の海岸 に適用するまでには, 後述する模型縮尺のその他の 諸問題を解決しなければならず，大規模模型実験が 可能な組織に今後の開発を委ねざるを得ない，その ため, 未だ検討不十分な項目が若干残るものの, こ れまでの成果をひとまず取りまとめ, 今後の実用研 究の参考に供する次第である.

\section{2. 特殊形状の人エリーフに関する既往研究}

波の屈折現象を利用して砕波を促進する試みとし ては，今井ほかの研究9)がまず挙げられる。これは 潜堤ではないが, クレセント型の没水水平板の背後 で波高が高まることを数值計算と実験で確認してお り, 海域制御施設の開発研究の一つである.

次には, 平沢ほか ${ }^{(0)}$ が横型人エリーフの左右約 $1 / 4$ を平均水面上に高めた複合型人エリーフについ て研究した.これは, リーフの一部を干出させるこ とで周辺を航行する漁船の座礁を予防するとともに, 循環流を積極的に発生させて水産物増殖に役立てよ うとするものである.

武若・入江ほか ${ }^{(1) \sim 13)}$ は直角三角形状の潜堤をテ 一パー型潜堤と呼び, 波向, 沿岸流, および海浜地 形を制御する可能性を検討した。 三角形の潜堤は, 斜辺を沖側に置き，長辺を等深線に平行に配置する.

これに対して渡辺・磯部のグループ(14),15) は，三 角形の斜辺を岸側に置き, 波が潜堤上から出るとき に全反射を起こすことで透過波が小さくなる効果を 狙っている。

また鈴木ほか ${ }^{(6)}$ は, 多数の三角形状の潜堤を沿岸 に平行に配置し, フレネルレンズと類似の屈折機能 を発揮させて波向を汀線に垂直に偏向させることを 狙い,これをフレネル潜堤と呼んだ.
一方，中野ほか ${ }^{17)}{ }^{18)}$ は波を集中させてサーフィ ンに適した砕波条件を造り出すことを目的として, 鋭角の二等辺三角形状の潜堤を沖へ向けて配置する ことを検討しており，デルタ型リーフと称している. このように, 通常の横型人エリーフの性能を向上 させる試みは数多くなされている. 水理模型実験で 水理特性を把握しつつ, 数值解析で機能を確認する ものが多い.ただし, 平沢ほか ${ }^{10)}$ の複合型人エリー フが北海道の胆振海岸を対象としたのを除くと, 本 論文で紹介する縦型人エリーフを含め, いずれも研 究室での構想にとどまっている.

\section{3. 縦型人エリーフ周辺の波浪変形の解析}

\section{（1）波動方程式の選択}

人エリーフの性能検討では, まず最初にリーフ周 辺の波浪変形を解析しなければならない。 その結果 を基にラディエーション応力を計算し, 水位変化と 海浜流を算出する。これまでの諸研究では, 緩勾配 方程式 ${ }^{17)}$, 放物型方程式 ${ }^{(1), 12)}$, 強非線形・強分散性 波動方程式 ${ }^{15)}$ ，ブーシネスク方程式 ${ }^{(6)}$ その他が使 用されている.

波動方程式の選択に際しては, 次のような要件を 考慮する必要がある.

(1)波浪変形の予測精度が高く, 水理模型実験との 整合性がよいこと.

(2)複数の形状の性能比較が容易に行えるように,

計算時間が少なくて済むこと.

(3)実際問題への対応を考慮し, 不規則波の計算が 可能であること.

(4)波の非線形性も取り込み可能なこと.

これらの要件を全て同時に満足させることはむず かしい. 波動方程式の選択は, 現時点では研究者の 主観的判断に委ねられている. 現象の再現性にもっ とも優れているのはブーシネスク方程式と思われる けれども, 平面地形に不規則波を作用させる場合に は計算時間が非常に長くなり，一般的とはいえない. 本研究では, 平口・丸山 ${ }^{199,20)}$ による以下の放物型 方程式を基本に用いた。この方法は, 斜め入射波に よる屈折効果を的確に表現できることが特長である

$$
\begin{aligned}
\frac{\partial \phi}{\partial x}= & \left\{i\left(k_{x}+\frac{k_{y}^{2}}{2 k_{x}}\right)-\frac{1}{2 k_{x} c c_{g}} \frac{\partial}{\partial x}\left(k_{x} c c_{g}\right)\right\} \phi \\
& +\frac{i}{2 k_{x} c c_{g}} \frac{\partial}{\partial y}\left(c c_{g} \frac{\partial \phi}{\partial y}\right)-f_{D} \phi
\end{aligned}
$$

ここに, $\phi$ は速度ポテンシャル $, k_{x}, k_{y}$ は $x, y$ 方向 
の波数, $c$ は波速, $c_{g}$ は群速度, $i$ は虚数である また， $f_{D}$ は砕波減衰を表す関数である. 本研究では, 人エリーフ上の波の減衰は砕波によるものが支配的 であると判断し, リーフ透水層内のエネルギー減衰 は無視している.

\section{（2）波速・波数に対する非線形補正}

放物型方程式による数值計算は, まず縦型潜堤が 無限個並んでいるところへ波が正面から入射する場 合を想定し，その 1 基を取りだした形を対象とした. 2 次元造波水路を用いてその中央に潜堤 1 基を縦に 配置すると, 水路両側壁が鏡面となるので無限個配 列と同等となる.

縌型人工リーフは, 潜堤中心間隔 $(A+c=$ 水路 幅) $60 \mathrm{~cm}$, 天端長 $a=10 \mathrm{~cm}$, 底面間隔 $c=0 \mathrm{~cm}$, 天 端幅 $B=100 \mathrm{~cm}$, 水深 $h=12 \mathrm{~cm}$, 天端水深 $h_{c}=$ $2.0 \mathrm{~cm}$, 前後斜面の勾配 $1 / 2$, 縌斜面の勾配 $1 / 2.5$ を 基本とし, 波高 $2.6 \sim 4.6 \mathrm{~cm}$, 周期 $0.7 \sim 1.4 \mathrm{~s}$ の波を 対象とした．模型縮尺を $1 / 50$ に想定すると，水梁 $5.0 \mathrm{~m}$, 天端幅 $50 \mathrm{~m}$, 波高 $1.3 \sim 2.4 \mathrm{~m}$, 周期 $5 \sim 9 \mathrm{~s}$ の 条件に相当する.

人エリーフの模型はふるい目 $20 \sim 30 \mathrm{~mm}$ 通過の 砕石を中詰めとして整形し, 表面には波で崩されな いように大きめの砕石を敷き並べた.

模型リーフに規則波を作用させて観察していると， リーフの天端上では水深が小さいにもかかわらず, 波峰が大きな速度で前進する. 特に, 波が砕けると きには, 縦斜面の上の波峰よりも前方に突出する. これは波速が水深だけではなくて波高の影響も受け ているためである．微小振幅波の波速を計算に用い ると屈折による波の集中効果が実験よりも過大に現 れる. この波速 $c$ に対する非線形効果の補正法と して, 次の修正式を試行錯誤によって設定した4).

$$
c= \begin{cases}c_{A}\left[1+\frac{3}{8}\left(\frac{H}{h}\right)^{2}\right]^{1 / 2} & : \quad H<2 h \\ c_{A}\left[1+\frac{3}{8}\left(\frac{H}{h}\right)\right]^{1 / 2} & : \quad H \geq 2 h\end{cases}
$$

上式の $c_{A}$ は微小振幅波理論による波速, $H$ と $h$ は 各地点の波高と水深である. $H<2 h$ の領域における 関数形は 3 次近似ストークス波の波速式を採用し， 係数の $3 / 8$ は実験值と照合して設定した.

波数 $k_{x}, k_{y}$ は微小振幅波の值を波速増大率で除 することで非線形効果の補正とした。 ただし，群速 度については未補正のままとした。

式（2）による波速の補正効果を示す数値計算の

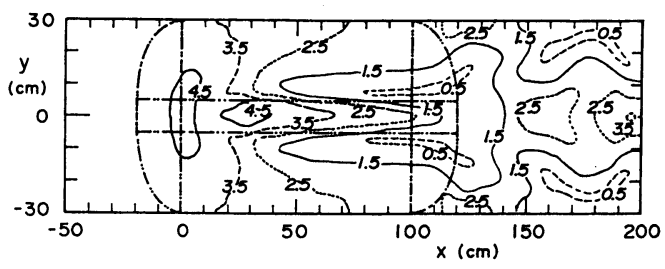

(a) 非線形効果未補正の場合

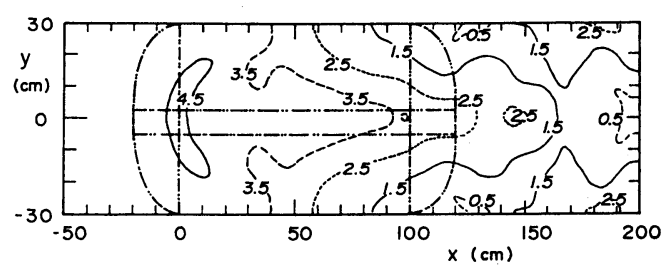

(b) 非線形効果を補正した場合

図-2 縦型人エリーフ周辺の規則波の等波高線図（単 位はcm) : $h_{c}=2.0 \mathrm{~cm}, H_{I}=4.2 \mathrm{~cm}, T=0.747 \mathrm{~s}$

例が図ー2である．上段は未補正の場合で，等波高 線（単位はcm）が局部的に大きく変化し，天端後 端の両側に波高の極小部分が現れる.これに対して 波速を式(2)で補正して計算すると下段のようにな り，屈折による波の集中が過度に現れることがなく， 水理実験で観測される傾向と合致する. なお, 数値 計算の格子間隔は, $\Delta x=\Delta y=2.5 \mathrm{~cm}$ である. 縦型 リーフの天端先端は $x=0 \mathrm{~cm}$, 後端は $x=100 \mathrm{~cm}$ に 位置しており, $y= \pm 30 \mathrm{~cm}$ は水路側壁である. また, 図中の $x, y$ 座標は縮尺がやや異なっている.

\section{（3）砕波減衰項の取り扱い}

人エリーフの研究では, 砕波による波エネルギー の減衰を的確に評価することがもっともむずかしい 一様斜面上での砕波でさえも基本的には実験で解明 するほかはなく, 最近の数值解析であっても実験デ 一タに依存するところが大きい，人エリーフのよう な急変地形での砕波限界および砕波後の波高减衰率 については, 模型実験の結果に合わせて砕波減衰項 を設定せざるを得ない。これまでの諸研究において も統一的な表式は得られていない.

平口・丸山 ${ }^{19)}$ が放物型方程式を提案したときには 地形変化が緩やかな場合を想定し, 渡辺・丸山の研 究 ${ }^{21}$ を参照して砕波減衰関数 $f_{D}$ を次のように設定 した.

$f_{D}= \begin{cases}0 & : \text { 砕波帯外 } \\ \frac{\alpha_{D} S_{D}}{2 h}\left[\left(\frac{H}{\gamma h}\right)-1\right]^{1 / 2}: & \text { 砕波帯内 }\end{cases}$ 


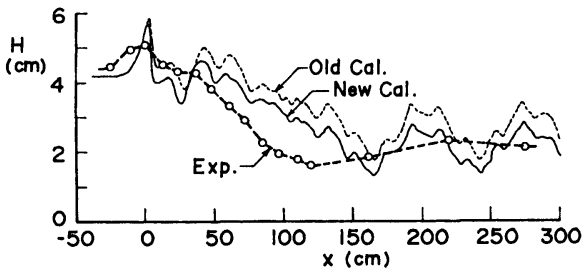

図ー3人エリーフ中心軸上の規則波の波高分布に及ぼ す砕波減衰関数の影響: $h_{c}=2.0 \mathrm{~cm}, H_{I}=4.2 \mathrm{~cm}$, $T=1.17 \mathrm{~s}$

ここに， $\alpha_{D}$ は砕波減衰係数， $S_{D}$ は海底勾配， $\gamma$ は 砕波限界波高と水深との比率である.

この式（3）の関数を用いた計算值を実験結果と 比べると, 砕波直後の波高減衰の度合いが弱い傾向

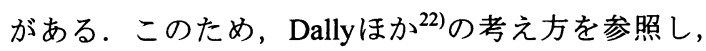
次式のように修正した関数を採用した ${ }^{4)}$.

$$
f_{D}= \begin{cases}0 & : \quad H<\mu h \\ \frac{K}{2 h}\left[\left(\frac{H}{h h}\right)^{2}-1\right]^{1 / 2}: & : H \geq \mu h\end{cases}
$$

なお，式（3）中に現れる海底勾配 $S_{D}$ は，人工リ 一フのような急変地形については定義が困難であっ て本来の意味を失っている. そこで係数 $\alpha_{D}$ と合わ せて新しい係数 $K$ に一本化し, 水理実験結果と比 較的よく対応する值として $K=0.125$ と定めた. こ の值は, Dallyほか ${ }^{21)}$ が斜面および水平床上の砕波 减衰に対して採択した $K=0.15$ に近い.

さらに, 砕波限界波高水深比 $\gamma$ についてこれまで の研究では一定值とする例が多い，しかし砕波限界 は水深波長比によって変化するので, 本研究では合 田 ${ }^{23)}$ の砕波指標式を導入して次のように設定した.

$$
\gamma=0.17 \frac{L_{0}}{h}\left\{1-\exp \left[-\frac{1.5 \pi h}{L_{0}}\left(1+15 \tan ^{4 / 3} \theta\right)\right]\right\}
$$

ここに $L_{0}$ は深海波長, $\tan \theta$ は海底勾配である. 人 エリーフの天端上に対しては換算勾配の意味を持た せ, 実験結果を参照して $\tan \theta=1 / 30$ を標準として使 用している. $\gamma$ の絶対值としては $0.8 \sim 0.9$ である.

二次元の矩形ステップ上の砕波限界である $\gamma \doteqdot 0.6$ の值 ${ }^{24)}$ と比べて大きいのは, 三次元地形の影響と考 えられる。

こうした砕波減衰項の妥当性を水理実験結果で 検証した例が図ーろである. 縦型人エリーフの天端 中心軸沿いの波高分布の実験と数值計算結果を示し ている. 図中の Old Cal.と記した細破線は式（3），
New Cal.と記した細実線は式（4）の砕波減衰関数 による結果である。波は規則波で, 入射波高 $H_{I}=$ $4.2 \mathrm{~cm}$, 周期 $T=1.17 \mathrm{~s}$ である. なお, 天端水深は $h_{c}$ $=2.0 \mathrm{~cm}$ であり, 数值計算では砕波限界指標として $\gamma=1.1$ とやや大きめの值を式（3），(4）ともに使 用した。二つの砕波減衰関数の差はあまり大きくな いが, 式（4）のほうが実験值に近い結果を与えて いる.こうした結果から，以下ではすべて式 (4) を用いて砕波減衰を評価している.

\section{（4）不規則波に対する計算}

人エリーフによる波の変形は天端上の砕波による 効果が大きく, 周期の影響はやや小さい. このため, 波のエネルギーの周波数帯域での広がりよりも個々 の波高と水深との比率の頻度分布が大きな影響を持 つ.したがって，不規則波に対しては波高の出現確 率を考慮した重㸚わせ計算を行うのが順当である。 具体的には，不規則入射波の波高がレーリー分布に 従うと仮定し，不規則波群を出現確率が等しい波高 区間に分割する．各区間の波高代表値は次式で選定 される.

$$
H_{m}=0.706\left(H_{1 / 3}\right)_{l}\left[\ln \frac{2 N}{2 m-1}\right]^{1 / 2}
$$

ここに $N$ は区間数， $m$ は波高の大きい方からの区 間番号である. 本研究では $N=30$ を使用している.

数値計算では各代表波高毎に規則波としての計算 を行い, その結果を計算地点ごとにエネルギー合成 する．たとえば, $1 / 10$ 最大波高であれば上位 $N / 10$ の結果の 2 乗平均平方根値をとり，有義波高であれ ば上位 $N / 3$ を平均する.

不規則波に対する縦型人エリーフの実験は，図一 2, 3 と同じ形状で 2 次元造波水路で行った. 表一 1 は実験条件と波高伝達率の結果を示している。 ま た，図ー4はこのうちの Case BとEについて等波高 比線の分布を実験と数値計算について示したもので ある. 上段は実験結果, 下段は数值計算である.こ の図に示すように, 波高は空間的な変化が大きい. このため, リーフ背後の波高の代表值としては, リ 一フ背後の長さ $1.0 \sim 2.0 \mathrm{~m}$ の範囲の有義波高の測定 値・計算值の 2 乗平均平方根值を用い, この代表波 高の入射波高に対する比で波高伝達率を定義した.

表一 1 では波高伝達率の計算值が実験值とほぼ一 致しており, 本研究で採択した数值計算法が妥当で あることを例示している. なお, Case A で実験値 が計算值よりも 2 割近く小さいのは, 計算で無視し たリーフ内部の流体抵抗および砕石表面の摩擦損失 による影響と考えられる. 


\begin{tabular}{|c|ccccc|}
\hline Case & $h_{c}$ & $\left(H_{1 / 3}\right)_{I}$ & $T_{1 / 3}$ & \multicolumn{2}{c|}{$K_{T}$} \\
& $(\mathrm{~cm})$ & $(\mathrm{cm})$ & $(\mathrm{s})$ & Exper. & Comp. \\
\hline $\mathrm{A}$ & 4.0 & 2.58 & 0.96 & 0.729 & 0.927 \\
$\mathrm{~B}$ & 4.0 & 4.57 & 0.98 & 0.666 & 0.711 \\
$\mathrm{C}$ & 2.0 & 3.64 & 0.83 & 0.482 & 0.437 \\
$\mathrm{D}$ & 2.0 & 3.32 & 1.09 & 0.561 & 0.533 \\
$\mathrm{E}$ & 2.0 & 3.72 & 1.27 & 0.557 & 0.539 \\
\hline
\end{tabular}
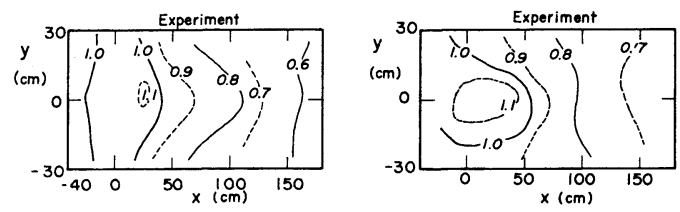

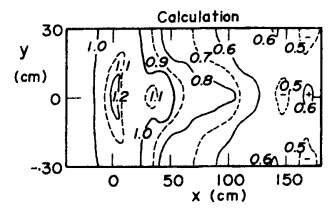

(a) Case B

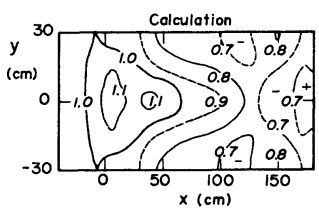

(b) Case E
図ー4 実験および計算による不規則波の等波高比線図

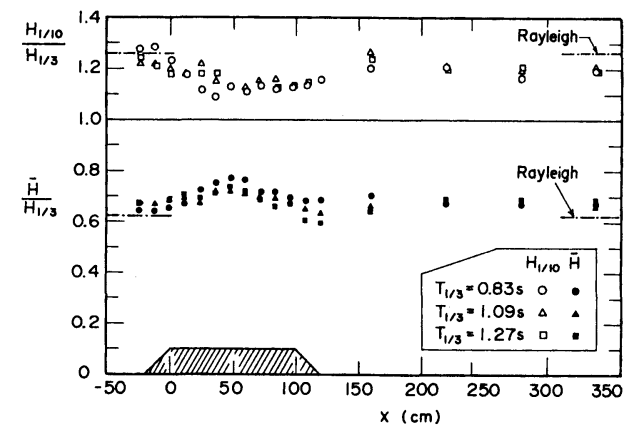

図ー5 縦型リーフ中心軸上の波高比の変化

$$
: h_{c}=2.0 \mathrm{~cm},\left(H_{1 / 3}\right)_{I}=3.3 \sim 3.7 \mathrm{~cm}
$$

なお，不規則波では波高の大きな波ほど砕波減衰 の影響を強く受けるため, 波群中の波高分布が変化 する. 図ー 5 は，縦型人エリーフの中心軸上の測点 における波高比 $H_{1 / 10} / H_{1 / 3}$ と $H_{1 / 3} / H$ の実験值を, Case C, D, Eについてまとめて表示したものである. リーフの天端上では波高分布の幅が狭まり, $1 / 10$ 最 大波高 $H_{1 / 10}$, 有義波高 $H_{1 / 3}$, および平均波高 $H$ の 差が縮まって波高比が 1.0 に近づく．しかしリーフ の背後では本来のレーリー分布の比率に戻っていく. 波高区間の重ね合わせ方式による数值計算でもこう した傾向が認められたけれども, 局所的な変動が大 きいために実験值ほど明確ではなかった。
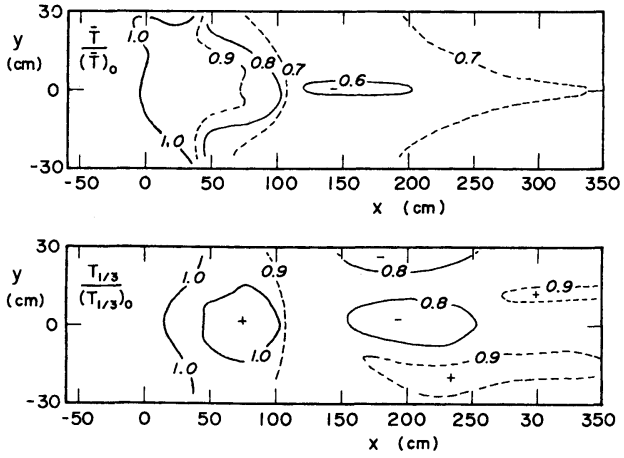

図ー6 繸型リーフ周辺における周期の変化 : $h_{c}=2.0 \mathrm{~cm},\left(H_{1 / 3}\right)_{I}=3.7 \mathrm{~cm}, T_{1 / 3}=1.27 \mathrm{~s}$

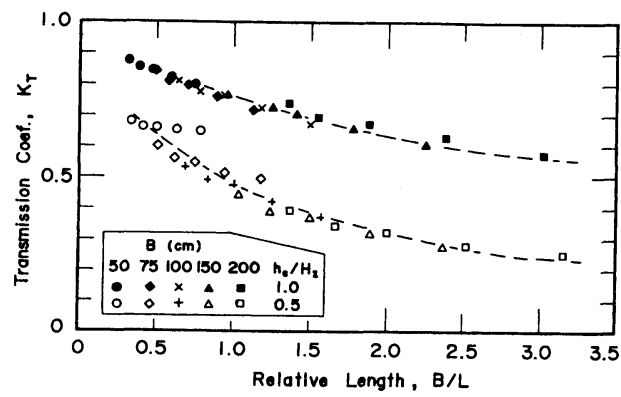

図-7 縌型リーフの波高伝達率 $K_{T}$ と相対天端幅 $B / L$ の関係 : $\left(H_{1 / 3}\right)_{I}=4.0 \mathrm{~cm}, T_{1 / 3}=0.7 \sim 1.4 \mathrm{~s}$

\section{（5）不規則波の周期変化}

さらに，不規則波では代表周期もまた変化する. これは急変地形上で波の分裂が起きるためである. 今回の数值計算では再現できないが，実験では明瞭 に現れた. 図ー6は Case E の結果であり，上段は 平均周期 $T$ の変化, 下段は有義波周期 $T_{1 / 3}$ の変化を 示す. 人工リーフの背後では周期が短かくなってお り,この変化は平均周期のほうが著しい.

\section{（6）天端幅と波高伝達率の関係}

縦型人工リーフは天端幅 $B か ゙$ 増すにつれて波浪減 衰の度合が強まる. 水理実験は $B=100 \mathrm{~cm}$ のケース しか行っていないが，表－1 や図ー4に示すように 数値計算はこうした実験結果を順当に再現している と判断されるので, 数值計算に基づいて天端幅の効 果を検討した。

縦型人エリーフの堤高は $t=10 \mathrm{~cm}$ に固定し, 水位 を変えることで天端水深を $h_{c}=2.0 \mathrm{~cm}$ と $4.0 \mathrm{~cm}$ の 2 種類とした，波は入射波高を $\left(H_{1 / 3}\right)_{I}=4.0 \mathrm{~cm}$ に固定 し, 周期を $T_{1 / 3}=0.7 \sim 1.4 \mathrm{~s}$ の 5 通りとした. そして 


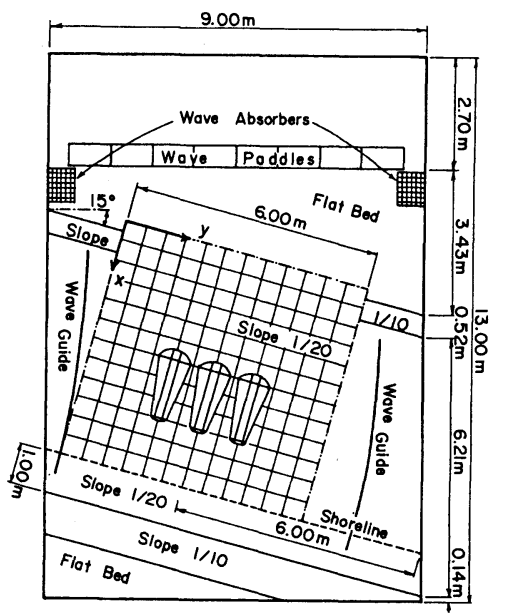

図ー8 平面実験用の水槽とリーフ模型の配置

天端幅を $B=50 \sim 200 \mathrm{~cm}$ の範囲で 5 段階に設定した. 波高伝達率は, リーフ後端から $0.5 \sim 1.5 \mathrm{~m}$ の長さ $1.0 \mathrm{~m}$ の範囲の有義波高の 2 乗平均平方根值を用い て定義した。

波高伝達率の計算結果は, 図一 7に示すとおりで ある. 図中の $L$ はリーフ設置水深における微小振 幅波の波長である. 波高伝達率 $K_{T}$ は天端幅および 周期の絶対值にかかわりなく, 相対天端水深 $h_{c} / H_{I}$ $=0.5$ および 1.0 の值ごとにそれぞれ 1 本の曲線 にほぼ乗っている. すなわち, 縦型人エリーフの波 浪減衰機能は相対天端水深 $h_{d} / H_{I}$ と相対天端幅 $B / L$ の二つのパラメータによって支配されるといえる.

\section{4. 複数基配置の縦型人エリーフの特性}

\section{（1）平面模型実験水槽とリーフ模型}

前節の検討によって, 縦型リーフが無限個並んだ ところへ波が正面から入射する場合の波浪减衰機能 は明らかになった。 そこで，もう少し現実的な状況 として, 縦型リーフが 3 基配置されたところへ波が やや斜めから入射する状況を対象とし, 平面造波水 槽での水理実験と数值計算を行った ${ }^{6)}$.

実験水槽と模型リーフの配置は図ー8に示すとお りである. 幅 $9.0 \mathrm{~m}$, 長さ $13.0 \mathrm{~m}$ の屋外水槽内に造 波板と 15 度の角度を付けて勾配 $1 / 20$ のモルタル斜 面を法面長 $6.0 \mathrm{~m}$ にわたって敷きならした．その先 端は取り付けの関係で法面長 $0.5 \mathrm{~m}$ の勾配 $1 / 10$ 斜面 とした。 また, $1 / 20$ 勾配斜面の後端の岸側は勾配 1/10のモルタル斜面とした. 実験はすべて造波板前

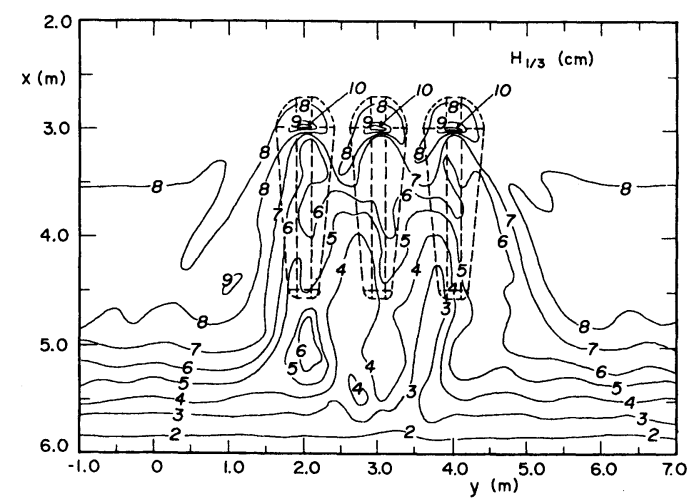

図-9 縦型リーフシステム周辺の不規則波Aの波高分 布の計算結果 : $\left(H_{1 / 3}\right)_{I}=7.5 \mathrm{~cm}, \quad T_{1 / 3}=1.2 \mathrm{~s}$

面の水平床部分の水深を $0.3 \mathrm{~m}$ に設定して行った. したがって, 汀線は勾配 $1 / 20$ 斜面と $1 / 10$ 斜面の接 続部から造波板側へ $1.0 \mathrm{~m}$ 下がった位置にある. 水 槽内の模型配置などについては, 勾配 $1 / 20$ 斜面を仮 想的に延長して水平床と交差する線を $x$ 軸とし，そ れと直交する $y$ 軸を設定し，この直交座標で説明す る.

縦型人エリーフの模型は 3 基とし, 天端水深 $h_{c}$ $=3 \mathrm{~cm}$, 天端長 $a=10 \mathrm{~cm}$, 天端幅 $B=150 \mathrm{~cm}$ とし, 粒径 30〜 50mm の砕石で形作った。 ただし, 作業効 率を上げるため内部には粒径 100〜150mm の大型砕 石も使用した。前後斜面の勾配は $1 / 2$, 繸斜面の勾 配は $1 / 2.5$ である. 3 基のリーフは, 頂部の前端を $x$ $=3.0 \mathrm{~m}$ (水深 $15 \mathrm{~cm}$ ) の位置に揃えて設置した. 人工 リーフの底面の長さは設置斜面の勾配が $1 / 20$ と急 なために, 前端と後端で異なり, 前は $A=a+2 s=$ $80 \mathrm{~cm}$, 後ろは $A=42 \mathrm{~cm}$ となった. 3 基のリーフは 中心軸間隔を $A+c=100 \mathrm{~cm}$ として設置した.

実験には，有義波高 $\left(H_{1 / 3}\right)_{I}=7.5 \mathrm{~cm}$ で周期 $T_{1 / 3}=$ $1.2 \mathrm{~s}$ の不規則波 $\mathrm{A}$ ，および有義波高 $5.5 \mathrm{~cm}$ で周期 $1.6 \mathrm{~s}$ の不規則波 B $の 2$ 種類を用い，数值計算も同じ 条件で実行した. この 2 種類の波は, 斜め斜面を持 つ水槽内で発生させた波のうちで安定性に優れてい たものである. なお，測定領域の両側の導波板は， 発生波の屈折状況を観察しながら妥当と思われる位 置に固定した。

\section{（2）波高分布}

放物型方程式による不規則波の波高分布の計算は 前節に述べた方法のままである. 入射角として水深 $30 \mathrm{~cm}$ の沖側境界で 15 度を入力しただけである. な お，格子間隔は計算領域が広いことを考えて $\Delta x=$ $\Delta y=0.1 \mathrm{~m}$ とし, 沿岸方向に 85 格子, 岸沖方向に60 


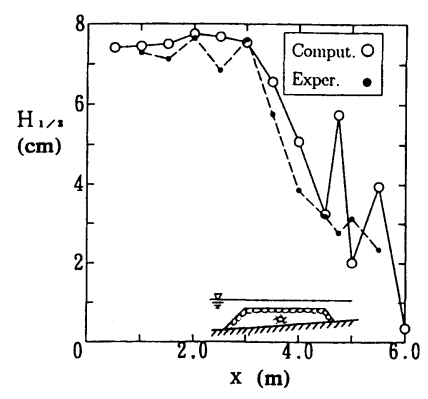

（a） 不規則波 A： $\left(H_{1 / 3}\right)_{I}=7.5 \mathrm{~cm}, \quad T_{1 / 3}=1.2 \mathrm{~s}$

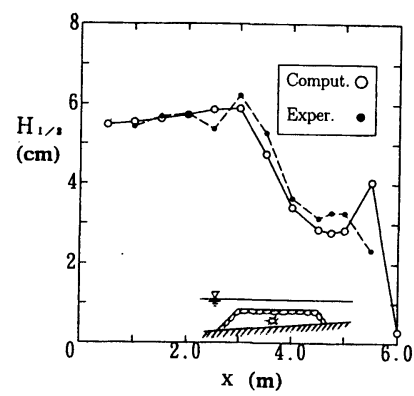

（b） 不規則波 B : $\left(H_{1 / 3}\right)_{I}=5.5 \mathrm{~cm}, T_{1 / 3}=1.6 \mathrm{~s}$

図-10 縦型リーフシステムの岸沖方向 $(y=2.5 \mathrm{~m})$ の波高分布

格子を設定した。

図ー9は数值計算で得られた縌型リーフシステム 周辺の波高分布,の例であり, $\left(H_{1 / 3}\right)_{I}=7.5 \mathrm{~cm}, T_{1 / 3}=$ $1.2 \mathrm{~s}$ の場合である. リーフ先端部で波高が急増して から落ち込み, リーフシステム背後の波高が低減し ている状況が伺える．また，波は図の左上方から入 射しており，リーフシステムの右側がやや静噯にな っている．なお，図の縦軸は横軸よりも長く引き伸 ばされているので注意されたい.

こうした波高の平面分布のうち, 左から 1 番目と 2 番目のリーフの間の $y=2.5 \mathrm{~m}$ の線に沿って岸沖 方向の波高分布を実験と計算で比較したのが図-10 である．上段が不規則波 $\mathrm{A} ，$ 下段が不規則波Bであ り，黒丸が実験，白丸が計算である．また，リーフ システム背後の $x=4.75 \mathrm{~m}$ (リーフ頂部の後端から $0.25 \mathrm{~m})$ の線に沿って沿岸方向の波高分布を実験と 計算で比較したのは図ー11である.

縦型リーフ間の岸沖方向の波高分布は, 図一10に 見られるように実験值と計算結果がかなりよく一致 している. 沿岸方向の分布はリーフシステムの外側 の計算値が過大であり，図ー11(a)のケースで顕著

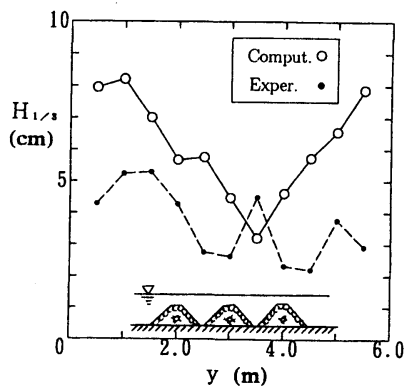

（a） 不規則波 A : $\left(H_{1 / 3}\right)_{I}=7.5 \mathrm{~cm}, T_{1 / 3}=1.2 \mathrm{~s}$

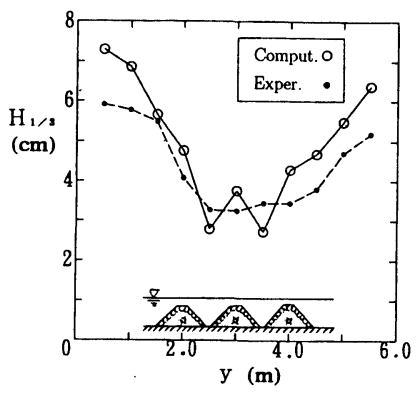

（b） 不規則波 B : $\left(H_{1 / 3}\right)_{I}=5.5 \mathrm{~cm}, T_{1 / 3}=1.6 \mathrm{~s}$

図-11 縦型リーフシステムの沿岸方向 $(x=4.75 \mathrm{~m})$ の波高分布

に現れている．この差異は，式（4）の波高減衰関 数の持つ問題点が, 式（6）の波高重ね合わせ方式 と組み合わせたことで顕在化したものと考えられる すなわち，規則波では $H_{b}=\gamma h$ が限界波高とな り，砕波帯内では水深の減少に応じて波高が減衰す るとみなされる．不規則波の各波高区間にこの規則 波の砕波の考え方を適用すると，ある限度以上の波 高区間の波はすべて規則波の限界波高に揃ってしま う.このため, 波高分布としては $H=H_{b}$ の位置に 確率密度が集中する形となる. 実際の不規則波の砕 波はこれとは異なり，著者のモデル25)で表されるよ うに，砕波限界を超えた波はエネルギーの再配分に よって波高の小さな波に再生され，波高分布が 1 個 所に集中することがない.

この式（4）の問題点は規則波ではあまり目立た ず，不規則波のときに顕著になる. 一つの解決策と しては, 最初に砕波する限界波高と砕波後に減衰し て到達する安定波高の二つの限界值を用い，何らか の遷移区間を導入する方式 ${ }^{26)}$ が考えられよう. 今後 の検討課題の一つである. 
（3）海浜流と水位の分布

\section{a）流れと水位の計算の基本式と計算条件}

海浜流の $x, y$ 軸方向の断面平均流速 $U, V$ およ び平均水位の上昇量

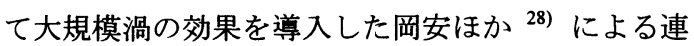
続・運動方程式を数值解析して求めた.

入力は波動場の計算で得られた各格子点のラディ エーション応力である.これは各地点の波高に基づ いてエネルギー密度を算定し, 同じく放物型方程式 から得られる各地点の波向を導入してラディエーシ ヨン応力の各成分を求めた.

計算は初期静止状態から開始し，ラディエーショ ン応力は緩始動方式で与えた. すなわち, 開始時は 0 とし, 時間ステップ 400 回の時間をかけて所定の 值になるように直線的に増加させた．数值計算には 差分法を用い, 空間微分は中央差分, 時間微分は前 方差分である. 空間格子は波浪場と同一の $0.1 \mathrm{~m}$ 間 隔の正方形で, 時間ステップは $\Delta t=0.05 \mathrm{~s}$ とした.

底面摩擦項は海浜流と底面水粒子速度との合成流 速を用いて計算し, 摩擦係数は $C_{f}=0.01$ を使用した. 水平拡散項のうちの渦動粘性倸数は LonguetHiggins $^{29}$ が導入した $N=0.016$ の無次元定数をその まま用いた。

境界条件としては, 水槽内に設置した導波板の位 置で法線方向速度を 0 とする固定壁条件である.こ のため, 長方形の計算領域の中で導波板に相当する 格子位置で人為的に流速 0 の条件を設定することで 処理した.

\section{b) 海浜流と水位の計算結果}

まず，図-12 は不規則波 $\mathrm{A}$ の場合の平均水位の 計算結果である.この図は波高分布を表す図ー9に 対応しており, 波高が急増している縌型リーフの先 端部分で局所的に水位が低下している. 傾向として は縦型リーフの天端上で水位がやや低く, リーフの 間の水域でやや高くなっている. またリーフシステ ムの背後でも水位が高めである. 平均水位上昇量の 空間分布としては物理現象を反映しているけれども， 絶対值としては過小である. また, $y=5.0 \mathrm{~m}$ 付近に 平均水位が急変する個所が岸沖方向に伸びているの は, 側方境界の設定の関係で数值水槽内に循環流が 発生し，この個所に潮目のようなものが現れたため と思われる.

縌型リーフシステム周辺の海浜流の計算結果の例 を図ー13に示す。リーフ上の強い岸向きの流れは流 速が $50 \mathrm{~cm} / \mathrm{s}$ を超えており，天端水深 $3 \mathrm{~cm}$ に対する 長波の波速 $54 \mathrm{~cm} / \mathrm{s}$ にまで達している. リーフシステ ムの周辺では数個の循環流が形成されているが, こ の多くは今回の数値計算に特有のものと思われ,

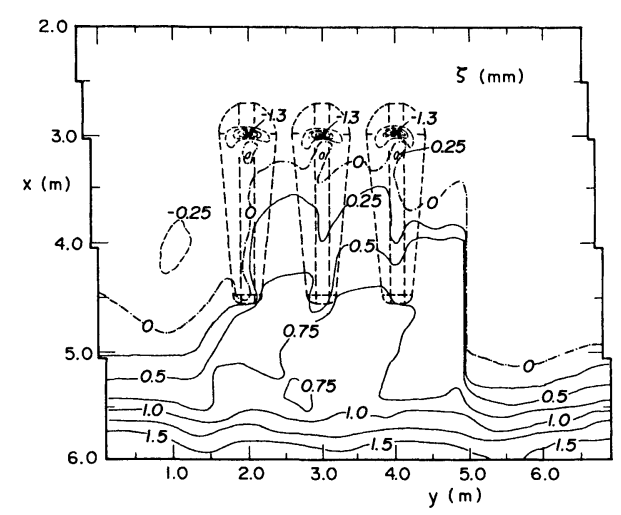

图一12 縦型リーフシステム周辺の不規則波 $\mathrm{A}$ による平 均水位の計算結果 : $\left(H_{1 / 3}\right)_{I}=7.5 \mathrm{~cm}, T_{1 / 3}=1.2 \mathrm{~s}$

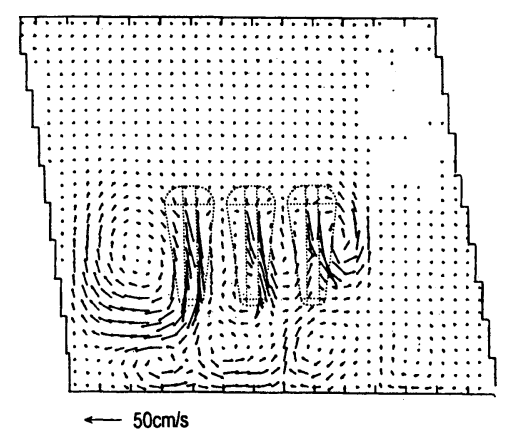

図ー13 縦型リーフシステム周辺の不規則波 $\mathrm{A}$ による海 浜流の計算結果 : $\left(H_{1 / 3}\right)_{l}=7.5 \mathrm{~cm}, T_{1 / 3}=1.2 \mathrm{~s}$

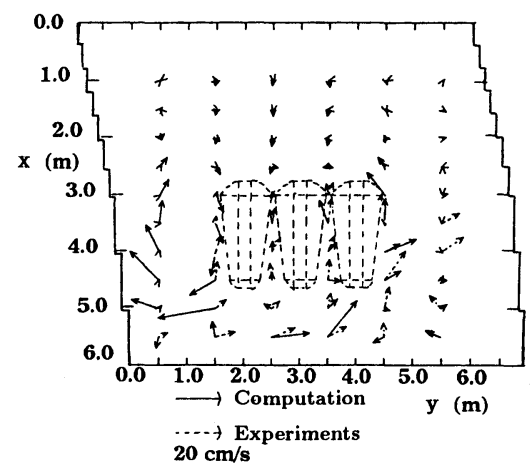

図-14 縦型リーフシステム周辺の海浜流の実験值と

計算値の比較 : $\left(H_{1 / 3}\right)_{I}=7.5 \mathrm{~cm}, T_{1 / 3}=1.2 \mathrm{~s}$

実験では確認されていない.

c）海浜流の実験と数值計算の比較

実験水槽内では2成分超音波流速計を用いて $50 \mathrm{~cm}$ 


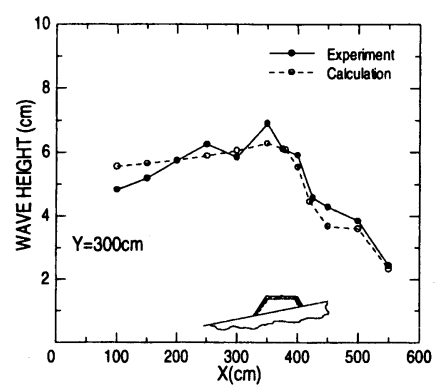

(a) $y=3.0 \mathrm{~m}$ の軸線上の波高分布

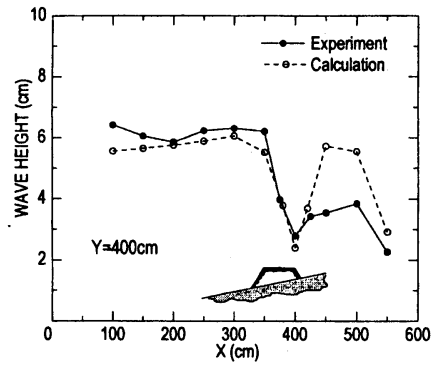

(b) $y=4.0 \mathrm{~m}$ の軸線上の波高分布

図ー15 横型リーフシステムの岸沖方向の波高分布 : 不規則波B : $\left(H_{1 / 3}\right)_{I}=5.5 \mathrm{~cm}, T_{1 / 3}=1.6 \mathrm{~s}$

の格子間隔で平均流速を測定した.この結果を数値 計算と比較した例を図一14 に示す。不規則波 A の ケースである. 数值計算で予测されたリーフ上の強 い流れは，目視でも確認された．ただし，波の谷の ときに流速計のセンサー部が干出するために流速值 を測定することができなかった.

リーフの間の水域には沖へ向かう離岸流があり, これは実験, 計算ともに認められる.この流速につ いては, 次節の横型人エリーフとの比較のところで 説明する.

\section{5. 横型リーフと縦型リーフとの比較}

\section{（1）横型人エリーフ周辺の波高分布}

先に図ー8に示した造波水槽内に，縦型リーフ 3 基とほぼ同体積の横型リーフ 2 基を設置した.リー フは天端長 $a=100 \mathrm{~cm}$, 天端幅 $B=45 \mathrm{~cm}$ であり, リ 一フ頂部の先端を $x=3.5 \mathrm{~m}$ の位置に揃え, リーフ中

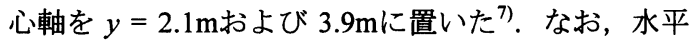
床上であれば，リーフ 1 基の体積は次の式（7）で

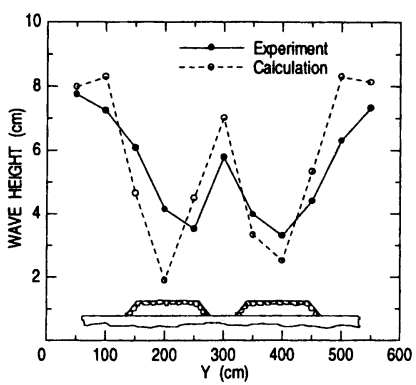

(a) $x=4.0 \mathrm{~m}$ の線上の波高分布

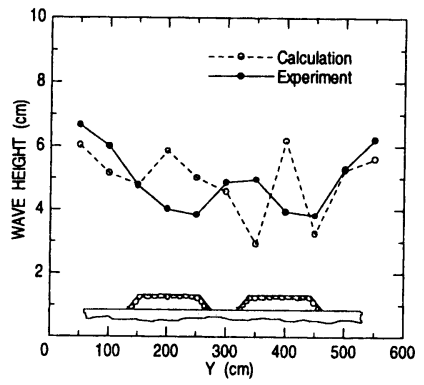

（b） $x=4.5 \mathrm{~m}$ の線上の波高分布

図ー16 横型リーフシステムの沿岸方向の波高分布 : 不規則波A : $\left(H_{1 / 3}\right)_{I}=7.5 \mathrm{~cm}, T_{1 / 3}=1.2 \mathrm{~s}$

概算できる.

$$
V=t\left[b\left(a+\frac{\pi}{3} s\right)+(a+s) B\right]
$$

実験に使用したのは縦型人エリーフと同じく不規 則波 A および B である.この横型リースシステム 周辺の波高分布の実験値と計算結果の比較を図 -15 , 16に示す. 前者は岸沖方向の波高分布であり, $y=$ $3.0 \mathrm{~m}$ は 2 基の横型リーフの間の軸線である. また, $y=4.0 \mathrm{~m}$ はリーフ天端を横切る軸線である. 後者の 場合にリーフの背後で計算が実験值を上回っている のは, 図一11に関連して述べた不規則波の砕波減衰 の取り扱いに起因する見かけの現象である.なお, 波高はいずれも有義波高である.

沿岸方向の分布は，図－16に示すように実験値と 計算結果がほぼ一致している． $x=4.0 \mathrm{~m}$ の線はリー フ頂部の後端から $5 \mathrm{~cm}$ 岸側であり, リーフの直背 後で波高が急减し, リーフの間の水域およびリーフ システムの外側で波高が大きくなっている． $x=$ $4.5 \mathrm{~m}$ の線はリーフをはずれた水域であり, 波高分 
表ー2 リーフ間の離岸流の最大値

\begin{tabular}{|c|c|c|}
\hline$H_{1 / 3} \quad T_{1 / 3}$ & 横型リーフ & 縦型リーフ \\
\hline$(\mathrm{cm})(\mathrm{s}$ & 実験值 計算值 & 実験値 計算值 \\
\hline 5.5 & $8.5 \mathrm{~cm} / \mathrm{s} \quad 13.2 \mathrm{~cm} / \mathrm{s}$ & $8.3 \mathrm{~cm} / \mathrm{s} \quad 10.5 \mathrm{~cm} / \mathrm{s}$ \\
\hline 7.5 & $12.0 \mathrm{~cm} / \mathrm{s} 28.5 \mathrm{~cm} / \mathrm{s}$ & $11.4 \mathrm{~cm} / \mathrm{s} \quad 15.0 \mathrm{~cm} / \mathrm{s}$ \\
\hline
\end{tabular}

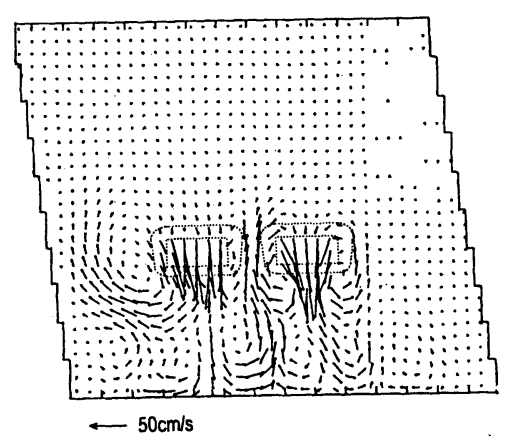

图ー17 横型リーフシステム周辺の不規則波 $\mathrm{A}$ による海 浜流の計算結果 : $\left(H_{1 / 3}\right)_{I}=7.5 \mathrm{~cm}, T_{1 / 3}=1.2 \mathrm{~s}$

布がやや一様化している.

この図-15，16の結果は, 本研究で取り扱った放 物型方程式に基づく不規則波の重ね合わせ方式によ って, 縦型人エリーフだけでなく, 通常の横型人工 リーフ周辺の波高分布を算定できることを例示して いる.

\section{（2）横型および縦型人エリーフ周辺の海浜流}

横型人エリーフシステム周辺の海浜流を計算した 結果を図一17に示す。対象とした波は不規則波 $\mathrm{A}$ であり, 縦型の場合の図一13に対応するものである. 横型システムではリーフ上の岸向きの流れがリーフ 中央に集中し，またリーフの間の水域を沖向きに流 れる離岸流が強く現れている。

そこで, リーフ間の離岸流速について, 実験およ び計算で得られた最大値を拾い出し, 横型と縦型で 比較してみた. 表一 2 はその結果である. 数値計算 では横型リーフシステムのほうが縦型システムより もかなり大きな流速となっている. ただし, 実験結 果では横型システムの離岸流がわずかに速い程度で あり, 計算のような顕著な差が得られなかった。一 つの理由として, 実験では $50 \mathrm{~cm}$ 間隔で流速を測定 したため, 流速の最大値を確実には捕捉できなかっ た可能性が考えられる.

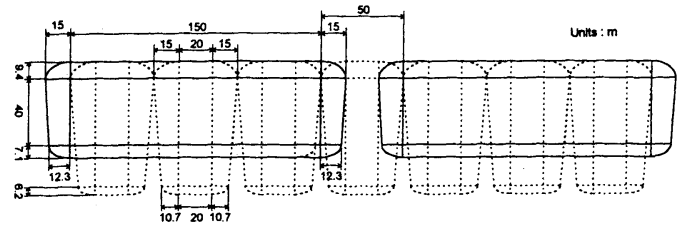

図ー18 想定した現地海岸でのリーフの平面形状

（3）横型リーフと縦型リーフの波高減衰機能の比較 以上はすべて模型規模での検討であった．特に， 平面配置では実験水槽の制約から勾配 $1 / 20$ と現地 海岸としては急斜面を使用せざるを得なかった．そ こで, 本研究の波浪変形計算プログラムを利用して 現地規模で横型人エリーフシステムと縦型システム を比較してみた。

計算領域は沿岸方向 $1000 \mathrm{~m}$, 岸沖方向 $445 \mathrm{~m}$, 海 底勾配は $1 / 50$ でその沖側は水深 $10 \mathrm{~m}$ で一定とした。 そして, 水哚 $6.0 \mathrm{~m}$ の地点から岸側に人エリーフを

設置することを想定した．波は水深 $10 \mathrm{~m}$ 地点で 15 度の角度で入射するとした。

横型人エリーフは天端長 $a=150 \mathrm{~m}$ で天端幅 $B=$ $40 \mathrm{~m}$ のものを, 頂部で $50 \mathrm{~m}$ の間隔で 2 基設置する とした. 縦型リーフは天端長 $a=20 \mathrm{~m}$ で天端幅 $B=$ $65 \mathrm{~m}$ のもの 7 基を連続させた. 天端水深はいずれも $h_{c}=1.5 \mathrm{~m}$, 縦斜面の勾配は $3 / 10$ とした. リーフの寸 法を図ー18に示す.リーフ先端の海底面での長さは 横型システムで $380 \mathrm{~m}$, 縌型システムで $350 \mathrm{~m}$ であ る.

計算は，低規模波浪として有義波高 $1.0 \mathrm{~m}$, 周期 $8 \mathrm{~s}$ ，および中規模波浪として有義波高 $3.0 \mathrm{~m}$, 周期 $8 \mathrm{~s} の 2$ 種類の波を対象とした。図一19はそその結果 であり，(a) は低規模波浪，（b) は中規模波浪に対す る沿岸方向の波高分布を示している. それぞれ上段 の $=330 \mathrm{~m}$ の位置はリーフ頂部の先端から $50 \mathrm{~m}$ 岸側 で水梁 $5.0 \mathrm{~m}$, 下段の $x=380 \mathrm{~m}$ はリーフシステムの背 後で水深 $4.0 \mathrm{~m}$ の位置である. 実線は横型リーフシス テム, 破線は縦型リーフシステムの波高分布を示し ている.

この計算結果では, リーフの上では横型リーフシス テムのほうが波高がやや小さいが，リーフシステム の背後では縦型のほうが波高減衰の度合いが大きく， 特に低規模波浪のときにその差が顕著である.すな わち, 縦型リーフが波の屈折作用を利用して効果的 に砕波させ，減衰させていることが明瞭である. 

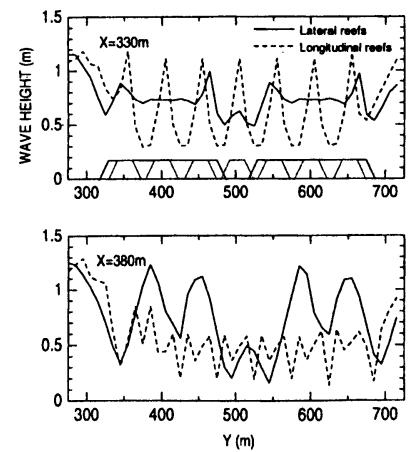

（a）低規模波浪 $\left(H_{1 / 3}=1.0 \mathrm{~m}, T_{1 / 3}=8 \mathrm{~s}\right)$
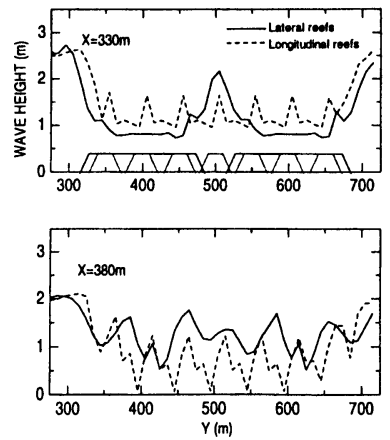

（b） 中規模波浪 $\left(H_{1 / 3}=3.0 \mathrm{~m}, \quad T_{1 / 3}=8 \mathrm{~s}\right)$

図ー19 横型システムと縌型システムの 沿岸方向の波高分布の比較

\section{6. 今後の検討課題}

最初に述べたように, 綐型人エリーフシステムは 通常の横型リースシステムに比べて水産協調型施設 として利用可能であり，また施工性も優れている. 本研究では詳細には検討しなかったけれども, リー フ背後の水位上昇が少ないので, リーフ周辺の海底 砂地盤の洗掘などの問題も少ないと予測される.し かし，この縦型リーフシステムを実用化するには以 下のような問題を解決する必要がある.

(1)大縮尺模型による砕波減衰状況の確認

(2)移動床模型による侵食防止効果の確認

(3)天端形状の最適化

(4)表面被覆材の安定性の検討

(5)多方向不規則波に対する応答の検証

まず最初の問題は, 砕波現象の縮尺効果の問題で ある. 本研究は天端水深は $h_{c}=2.0 \sim 4.0 \mathrm{~cm}$ の条件
で行っている．しかし，砕波に関しては一般に水深 $10 \mathrm{~cm}$ 以上でなければ水の表面張力の影響を受け, 現象の忠実な再現が出来ないとされている.このこ とは，台形ステップ上の砕波限界を対象とした合田 $ら^{30)}$ の実験でも確認されている，すなわち，勾配 $1 / 2$ の斜面に連なる水平床上の水深を $3.75 \mathrm{~cm}$,

$7.5 \mathrm{~cm}, 15.0 \mathrm{~cm}$ と変え, 波高・周期をフルード則で 相似させて実験を行ったところ，水深 $3.75 \mathrm{~cm}$ では 砕波限界と水深の比率が明らかに小さく現れた。 ま た, 砕波後の波高低減の状況は水深 $7.5 \mathrm{~cm}$ と $15.0 \mathrm{~cm}$ とで若干の差が見られた.したがって，急 変地形上の砕波に関しても水深 $10 \mathrm{~cm}$ 以上を確保す ることが望ましいといえる.

人エリーフに関しては模型実験による検討が数多 く行われているけれども，こうした砕波減衰の縮尺 効果を考えるならば現象の再現性については疑念が 残る. 本研究で取り上げた縌型人エリーフシステム を含め, かなり大縮尺の模型を用いて砕波現象を正 しく再現し, 砕波減衰関数 $f_{D}$ を的確に評価しなけ ればならない。

第 2 の移動床模型での検討は，人エリーフの主目 的が海岸侵食の防止であるだけに欠かすことができ ない. 特に, 従来の横型リーフシステムと比べて縦 型リーフシステムがどれだけの機能を発揮するかを 確認する必要がある.

第 3 の天端形状は, 縦型システムに固有のもので ある. 平沢ほか ${ }^{10}$ はこれまでの横型人エリーフでは 漁船が座礁する危険があるとして, リーフの両端を 干出させた複合型システムを提案している．縦型シ ステムではそれぞれのリーフの天端長が短いので, 先端部の一部を干出させてもなぎさからの景観を妨 げる度合いが少ない. また, 海上工事の施工性にも 問題はない，先端部を干出させることによって屈折 作用が増大し, 砕波減衰機能が高まることが期待さ れる.

次の表面被覆材の安定性は人エリーフ設計に際し ての大きな問題である. かなり大縮尺の模型実験で 検討しなければならない，ただし，縦型システムで はその 1 基を取り出した形を対象として 2 次元造波 水路内で実験すればよいと思われる.

最後の多方向不規則波については, 人エリーフが 浅水深に設置されることが多く，来襲波は海底地形 による屈折作用によって方向分散の度合いが小さく なっている. したがって, 1 方向不規則波の場合と 大きな差がないと推測されるけれども，実験あるい は数值計算で確認しておくことが望ましい。なお, 数値計算としてはブーシネスク方程式に基づく解法 を使用し，沖側境界で多方向不規則波の水位・流速 
の時系列を入力として与えることになるであろう．

\section{7. むすび}

本研究における主要な結論以下の 3 点である.

1) 縦型人エリーフシステムは, 波の屈折効果を取 り入れていることにより, 従来の横型リーフシス テムよりも波浪減衰機能が高い可能性がある.

2) 本研究で用いた放物型方程式を波高重ね合わせ 方式で不規則波に適用する解法は, 横型人エリー フシステムにも適用可能である. ただし, 最初に 砕波する限界波高と砕波後の安定限界波高の二つ を導入するなど改良が必要である.

3）放物型方程式を人エリーフシステムに適用する 際には，波速に対する非線形効果を導入しないと 波の屈折効果が過大に評価される.

しかしながら，最初にお断りしたように本研究に おける検討は必ずしも十分でない，特に，海浜流の 計算においては斜め入射波に対する側方境界の設定 など不完全であり，今後改良すべき余地が残されて いる. ただし，人エリーフシステムの性能向上の一 つの方向を示すものとして，あえてここに取りまと めた次第である，本論文を契機として，縌型人エリ ーフシステムに本格的に取り組んでいただける組織 が現れることを期待して本稿を終える次第である.

謝辞 : 本論文で紹介した研究は, 横浜国立大学工学 部建設学科において1991年度から1996年度にかけて 実施されたものである．学部の卒業研究として取り 組んでもらった山田晶子, 高橋真介, 高橋栄司, 吉 崎龍太郎, 原田智弘, および高木泰士の各位の協力 に深く感謝する次第である.

\section{参考文献}

1）宇多高明，田中茂信，筒井保博：人エリーフによる波 浪と漂砂の制御, 第 31 回海岸工学講演会論文集, pp.340-344, 1984.

2）大中 晋, 吉沢央明 : 人エリーフの天端幅の違いによ る波浪低减効果および反射率に関する現地調查, 海岸 工学論文集, pp.641-645, 1992.

3）合田良実，山田晶子：屈折効果を利用した縦型傾斜式 離岸堤の水理特性, 海岸工学論文集, 第39巻, pp.566$580,1992$.

4）合田良実, 高橋真介, 高橋栄司 : 放物型方程式による 縦型傾斜式離岸周辺の波浪場の解析, 海岸工学論文集, 第41巻, pp.986-990, 1994.
5) Goda, Y.: Wave damping characteristics of longitudinal reef system, Advances in Coastal Structures and Breakwaters, Clifford, J.E. ed., Thomas Telford Pub., London, pp.192-203, 1995

6) 合田良実, 吉崎龍太郎, 原田智弘 : 縦型傾斜式離岸堤 システム周辺の波高分布と海浜流について, 海岸工学 論文集, 第43巻, pp.121-125, 1996.

7) 合田良実, 高木泰士 : 人エリーフと繸型傾斜式離岸堤 の水理特性の比較について, 海洋開発論文集, Vol. 13, pp.31-36, 1997.

8) Goda, Y. and Takagi, H.: Lateral versus longitudinal artificial reef systems, Proc. $26^{\text {th }}$ Int. Conf. Coastal Engrg., pp.2152-3163, 1998.

9) 今井貫爾, 秋山義信, 池谷 毅, 工藤君明, 續 辰之 介：クレセント型没水平板の集波効果に関する研究, 第34回海岸工学講演会論文集, pp.487-491, 1987.

10) 平沢充成, 谷野賢二, 水野雄三, 渡透康玄, 大村高 史 : 複合型人エリーフの水理特性について, 海岸工学 論文集, 第37巻, pp.599-603, 1990.

11）武若 聡, 入江 功, 黒田 寛: テーパー型潜堤に よる波向制御, 海岸工学論文集, 第41巻, pp.726-730, 1994.

12) 武若 聡, 入江 功, 辻 利徳: テーパー型潜堤を用 いた沿岸流制御の試み, 海岸工学論文集, 第 41 巻, pp.731-735, 1994.

13）武若 聡, 入江 功, 山口 洋 : テーパー型潜堤に よる海浜地形制御の試み, 海岸工学論文集, 第 42 巻, pp.706-710, 1995.

14）坪田勇人, 磯部雅彦, 渡辺 晃：潜堤を用いた波浪 制御に関する研究, 海岸工学論文集, 第41巻, pp.641$645,1994$.

15）柿沼太郎, 渡辺 晃, 磯部雅彦: 三角形潜堤周辺の 砕波を伴う波, 流れ場の非線形数値計算, 海岸工学論 文集, 第44巻, pp.111-115, 1997.

16）鈴木康正, 上原 功, 冨田康大, 望月徳雄, 平石哲 也 : フレネル潜堤による波向, 波高変更効果に関する 模型実験, 海岸工学論文集, 第42巻, pp.701-705, 1995.

17）中野 晋, 三島豊秋, 中野孝二, 三井 宏 : サーフ インに適するデルタ型リーフ周辺の波浪特性, 海岸工 学論文集, 第41巻, pp.721-725, 1994.

18）中野 晋, 高田康史, 三島豊秋, 三井 宏 : サーフ イン共存型潜堤およびリーフ周辺の波浪特性, 海洋開 発論文集, Vol. 13, pp.19-24, 1997.

19) 平口博丸, 丸山康樹 : 斜め入射波に対する放物型方程 式の適用性の拡張, 第33回海岸工学講演会論文集, pp.114-118, 1986.

20) 平口博丸, 丸山康樹 : 斜め入射波に対する波浪変形計 算法一新しい放物型方程式の提案一, 電力中央研究所 
報告, U86045, 23p., 1987.

21) 渡辺 晃, 丸山康樹: 屈折, 回折, 砕波减衰を含む波 浪場の数値計算法, 第31回海岸工学講演会論文集, pp.103-107, 1984.

22) Dally, W.R., Dean, R.G., and Dalrymple, R.A.: Wave height variation across beaches of arbitrary profile, $J$. Geophys. Res., Vol. 90, No. C6, pp.11,917-11,927, 1985.

23）合田良実 : 防波堤の設計波圧に関する研究，港湾技術 研究所報告, 第12巻, 第3号, pp.31-69, 1973.

24) 合田良実, 岡崎健一：矩形ステップ上の非線形波浪千 渉と砕波限界, 海岸工学論文集, 第45巻, pp.46-50, 1998.

25) 合田良実 : 浅海域における波浪の砕波変形, 港湾技術 研究所報告, 第14巻, 第3号, pp.59-106, 1975.

26) 權赫珢, 合田良実 : バ一型地形における不規則波の砕 波変形について, 海岸工学論文集, 第42巻, pp.101-
$105,1995$.

27) 沼野祐二, 佐藤慎司, 柴山知也 : 海浜変形シミュレー ションにおける浮遊砂の移流過程とundertowの効果, 海岸工学論文集, 第36巻, pp.395-398, 1989.

28) 岡安章夫, 瀬尾貴之, 柴山知也 : 砕波による運動量輸 送を考虑した海浜流の準 3 次元モデル, 海岸工学論文 集, 第40巻, pp.251-255, 1993.

29) Longuet-Higgins, M.S.: Longshore currents generated by obliquely incident sea waves, 2, J. Geophys. Res., Vol. 75, No. 33, pp.6790-6801, 1970.

30) 合田良実, 森信耕太, 岡崎健一 : 水平ステップ上の砕 波限界に関する実験的研究, 海岸工学論文集, 第44巻, pp.66-70, 1987.

(1999. 9. 3 受付)

\section{A LONGITUDINAL ARTIFICIAL REEF SYSTEM UTILIZING WAVE REFRACTION EFFECTS}

\section{Yoshimi GODA}

A longitudinal, artificial reef system is composed of a number of long submerged mounds, which are placed in the nearshore zone with the orientation normal to the shoreline. Incoming waves are refracted by the heads and longitudinal side slopes of these reefs, and thus their heights are enhanced for intensive wave breaking. A series of small scale model tests and numerical computations have been carried out to confirm the performance of the new reef system, which is found to be superior to the conventional lateral system. Wave heights around the reef system can now be estimated through numerical analysis. The present paper summerizes the findings of these studies for the purpose of providing the basic data for future development of prototype reef systems. 